J. Perinat. Med. 17 (1989) 121

\section{Delivery of breech presentation infants at term. An analysis of 304 breech-deliveries}

\author{
Herbert Mecke, Dietrich Weisner, Iseult Freys, and Kurt Semm \\ Department of Obstetrics and Gynecology, University of Kiel and Michaelis- \\ Midwifery School, Kiel, West-Germany
}

\section{Introduction}

The mode of delivery of infants from breech presentation has been a ground for discussion for at least 3 decades [14, 15, 22]. In 1959 WRIGHT [22] propagated primary section as a mode of delivery in order to decrease fetal mortality and morbidity. In 1975 KUBLI [14, 15] called for the Caesarean Section of breech presentation infants from the $36^{\text {th }}$ gestational week on. Other authors $[3,6,12$, 19] suggest that Caesarean Section should generally be advised in premature births less than $2.500 \mathrm{~g}$ [3] or prior to completion of the $35^{\text {th }}$ gestational week [19] because of the elevated perinatal morbidity and mortality rates and the elevated incidence of disease in later life associated with vaginal delivery. The majority of researchers $[2,4$, $8,9,10,11,16,18]$ advise against Caesarean Section at term in principle due to the increased maternal risks. The German Society for Perinatal Medicine stands in agreement with this recommendation [1]. In the present study 304 breech deliveries of infants weighing $2.500 \mathrm{~g}$ or more are analysed with specific regards to the mode of delivery and perinatal morbidity and mortality.

\section{Material and methods}

Between 1984 and 1987370 breech presentation infants (table I) exclusive of multiple pregnancies were delivered; 304 weighed $2.500 \mathrm{~g}$ or more; 97 $(31.9 \%)$ were delivered vaginally; 207 (68.1\%) were delivered by Caesarean Section.

The proportion of vaginal deliveries of breech presentation infants rose from $11.5 \%$ in 1984 to $38.1 \%$ in 1987 . $32 \%$ of the vaginally delivered

\section{Curriculum vitae}

HeRBERT MECKe, M.D., studied medicine at the University of Marburg, where he obtained his Doctor title in 1978 and qualified in 1979. Since 1979 he has been a resident member of staff at the University Women's Clinic Kiel.

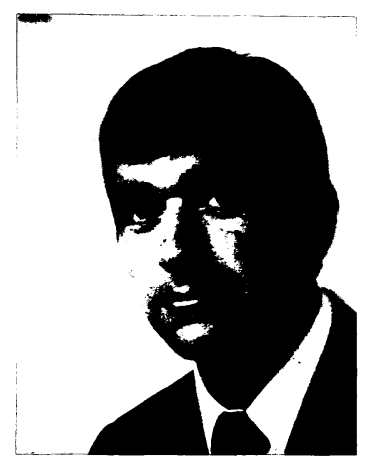

patients having a term breech presentation were primiparous. The mean age of the sectioned and vaginally delivered patients was 28.4 or 27.6 years respectively, thus demonstrating no significant difference.

\subsection{Criteria for establishing the mode of delivery}

There are only a few stringent recommendations in the choice of mode of delivery i.e. section or vaginal delivery. Absolute indications for Caesarean Section are:

- the suspicion of cephalo-pelvic disproportion

- elderly primigravida with rigid connective tissue

- placenta praevia

- umbilical cord prolapse in association with inefficient cervical dilatation.

Primiparity or premature rupture of membranes are not considered in our clinic as absolute indi- 
Table I. Deliveries between 1984-1987 and incidence of Caesarean Section in breech pregnancies.

\begin{tabular}{|c|c|c|c|c|c|}
\hline & 1984 & 1985 & 1986 & 1987 & $\Sigma$ 1984-1987 \\
\hline Deliveries & 1992 & 1956 & 2244 & 2400 & 8592 \\
\hline $\begin{array}{l}\text { Breech presentation } \\
\text { (non multiple } \\
\text { pregnancies) }\end{array}$ & $\begin{array}{l}78 \\
(3.9 \%)\end{array}$ & $\begin{array}{l}93 \\
(4.8 \%)\end{array}$ & $\begin{array}{l}97 \\
(4.3 \%)\end{array}$ & $\begin{array}{l}102 \\
(4.2 \%)\end{array}$ & $\begin{array}{l}370 \\
(4.3 \%)\end{array}$ \\
\hline $\begin{array}{l}\% \text { of vaginal } \\
\text { deliveries }\end{array}$ & $\begin{array}{l}10 \\
(12.8 \%)\end{array}$ & $\begin{array}{l}32 \\
(34.4 \%)\end{array}$ & $\begin{array}{l}40 \\
(41.2 \%)\end{array}$ & $\begin{array}{l}41 \\
(40.2 \%)\end{array}$ & $\begin{array}{l}123 \\
(33.2 \%)\end{array}$ \\
\hline $\begin{array}{l}\% \text { of deliveries by } \\
\text { caesarean section }\end{array}$ & $\begin{array}{l}68 \\
(87.2 \%)\end{array}$ & $\begin{array}{l}61 \\
(65.6 \%)\end{array}$ & $\begin{array}{l}57 \\
(58.8 \%)\end{array}$ & $\begin{array}{l}61 \\
(59.8 \%)\end{array}$ & $\begin{array}{l}247 \\
(66.8 \%)\end{array}$ \\
\hline $\begin{array}{l}\text { Breech deliveries } \\
\geqslant 2500 \mathrm{~g}\end{array}$ & 61 & 73 & 86 & 84 & 304 \\
\hline $\begin{array}{l}\% \text { of vaginal } \\
\text { deliveries }\end{array}$ & $\begin{array}{c}7 \\
(11.5 \%)\end{array}$ & $\begin{array}{l}23 \\
(31.5 \%)\end{array}$ & $\begin{array}{l}35 \\
(40.7 \%)\end{array}$ & $\begin{array}{l}32 \\
(38.1 \%)\end{array}$ & $\begin{array}{l}97 \\
(31.9 \%)\end{array}$ \\
\hline $\begin{array}{l}\% \text { of deliveries by } \\
\text { caesarean section }\end{array}$ & $\begin{array}{l}54 \\
(88.5 \%)\end{array}$ & $\begin{array}{l}50 \\
(68.5 \%)\end{array}$ & $\begin{array}{l}51 \\
(59.3 \%)\end{array}$ & $\begin{array}{l}52 \\
(61.9 \%)\end{array}$ & $\begin{array}{l}207 \\
(68.1 \%)\end{array}$ \\
\hline
\end{tabular}

$\%=$ percentage

Dept. of Obstet. \& Gynec., University of Kiel, 1988

cations for Caesarean Section. The decision whether to perform a Caesarean Section or a vaginal delivery is to be made after extensive counseling with each individual patient by an experienced obstetrician, taking the vaginal examination, the ultrasound examination, and varied risk factors into account.

If for example a primi- or multipara refuses vaginal delivery post-sterility therapy, a Caesarean Section is to be advised. The indication for a secondary section in the case of imminent intrauterine asphyxia, and protracted labour or primary uterine dysfunction should be generously applied.

\subsection{Procedure in the case of vaginal delivery}

Because in these cases Caesarean Section may be required an anaesthesiologist and a paediatrican must be present. Contraction in the $2^{\text {nd }}$ stage of labour can be augmented, when necessary, by continous oxytocin infusion. An effective lateral episiotomy is obligatory. The delivery of the infant is performed during one contraction using BRACHT's technique of manual assistance. This was achieved in $71.1 \%$. In cases where delivery of the arms failed using BRACHT's technique, the classical technique or that of BICKENBACH was applied.

\section{Results}

Most of the footling presentations were delivered by section; excluding these no dependence of the mode of delivery on the position of the breech infants could be proven.

Two of the vaginally delivered term infants died post-partum. In both cases kidney malformations had been sonographically diagnosed in the antepartum period. Post mortem revealed in one case a POTTER's syndrome, the child having died on the day of delivery, and in the second case polycystic kidneys type I POTTER where the child died 30 days post-partum of cardio-respiratory failure and anuria.

In the group of patients sectioned, no fetal deaths occurred. The perinatal morbidity of both groups was compared using the following parameters: Apgar scores, the rate of transfer to a paediatric unit, and the umbilical cord arterial $\mathrm{PH}$.

In $13.3 \%$ of cases post primary section and in $14.4 \%$ of cases post vaginal delivery from breech presentation we found an apgar of $\leqslant 7$ one minute post-partum. The transfer rate to a paediatric unit of vaginally delivered infants $(7.2 \%)$ appeared to be double that of the infants delivered per Caesarean Section (3.6\%). However, the indication for transferral is principally independent of the mode of delivery (table II). 
Table II. Transfer indications in breech presentation infants $\geqslant 2.500 \mathrm{~g}$ vaginally delivered $(\mathrm{n}=7)$.

- Hyperbilirubinaemia

- Post-partum asphyxia, 2730 g, female, P. H.art. 6.943, Apgar 3/7/9, delivery from frank breech presentation after PROM at term and protracted labour by manual assistance acc. to BRACHT, child at discharge: unremarkable

- Rhesus incompatibility

- Hypoglycaemia

- POTTER's syndrome

- Polycystic kidneys (type I POTTER)

- Lipomeningocoele in the sacral area

Dept. of Obstet. \& Gynec., University of Kiel, 1988
The fetal umbilical cord arterial PH in deliveries by primary Section ranged with its mean value of 7.30 significantly above the mean umbilical arterial $\mathrm{PH}$ of vaginal deliveries with a $\mathrm{PH}$ of 7.263 ( $p<0.001$ Students $t$ test) (table III). In a randomly selected collective of infants $\geqslant 2.500 \mathrm{~g}$ in the vertex presentation delivered per Caesarean Section we found also a significantly raised umbilical cord $\mathrm{PH}$ as compared to vaginal deliveries (table IV). There were no significant differences in the mean umbilical arterial PH between breech and vertex presentation infants, whether vaginally delivered or sectioned.

Table III. Umbilical cord arterial blood $\mathrm{PH}$ of breech presentation infants $\geqslant 2.500 \mathrm{~g}$ dependent upon mode of delivery $(n=246)$.

\begin{tabular}{|c|c|c|c|c|c|}
\hline \multirow{2}{*}{$\begin{array}{l}\text { Mode of } \\
\text { delivery }\end{array}$} & \multicolumn{5}{|c|}{ Umbilical cord arterial blood P. H. } \\
\hline & $<7.00$ & $7.00-7.09$ & $7.10-7.19$ & $\geqslant 7.20$ & $\begin{array}{l}\text { Average value of } \\
\text { umbilical cord } \\
\text { blood P. H. } \pm \mathrm{SD}\end{array}$ \\
\hline $\begin{array}{l}\text { Caesarean } \\
\text { section } \\
(n=165)\end{array}$ & $\begin{array}{l}1 \\
(0.6 \%)\end{array}$ & $\begin{array}{l}2 \\
(1.2 \%)\end{array}$ & $\begin{array}{l}6 \\
(3.6 \%)\end{array}$ & $\begin{array}{l}156 \\
(94.6 \%)\end{array}$ & $\begin{array}{r}7.303 \\
\pm 0.069\end{array}$ \\
\hline $\begin{array}{l}\text { Primary } \\
\text { section } \\
(n=153)\end{array}$ & $\begin{array}{l}1 \\
(0.7 \%)\end{array}$ & $\begin{array}{l}1 \\
(0.7 \%)\end{array}$ & $\begin{array}{l}5 \\
(3.3 \%)\end{array}$ & $\begin{array}{l}146 \\
(95.3 \%)\end{array}$ & $\begin{array}{r}7.304 \\
\pm 0.065\end{array}$ \\
\hline $\begin{array}{l}\text { Secondary } \\
\text { section } \\
(n=12)\end{array}$ & 0 & 1 & 1 & 10 & \\
\hline $\begin{array}{l}\text { Vaginal } \\
\text { delivery } \\
(n=81)\end{array}$ & $\begin{array}{l}2 \\
(2.5 \%)\end{array}$ & $\begin{array}{l}0 \\
(0.0 \%)\end{array}$ & $\begin{array}{l}16 \\
(19.7 \%)\end{array}$ & $\begin{array}{l}63 \\
(77.8 \%)\end{array}$ & $\begin{array}{r}7.263 \\
\pm 0.098\end{array}$ \\
\hline
\end{tabular}

Dept. of Obstet. \& Gynec., University of Kiel, 1988

Table IV. Umbilical cord arterial blood PH from vertex presentation infants $\geqslant 2.500 \mathrm{~g}$ as dependent upon mode of delivery $(n=400)$.

\begin{tabular}{lccccc}
\hline $\begin{array}{l}\text { Mode of } \\
\text { delivery }\end{array}$ & \multicolumn{4}{l}{ Umbilical cord arterial blood P. H. } & \\
\cline { 2 - 6 } & $<7.00$ & $7.00-7.09$ & $7.10-7.19$ & $\geqslant 7.20$ & $\begin{array}{l}\text { Average value of } \\
\text { umbilical.cord } \\
\text { blood P. H. } \pm \text { SD }\end{array}$ \\
\hline $\begin{array}{l}\text { Primary } \\
\begin{array}{l}\text { section } \\
(\mathrm{n}=100)\end{array}\end{array}$ & 0 & 0 & 8 & 92 & 7.304 \\
$\begin{array}{l}\text { Vaginal } \\
\text { delivery } \\
(\mathrm{n}=300)\end{array}$ & 0 & 3 & $(8.0 \%)$ & $(92.0 \%)$ & +0.068 \\
\hline
\end{tabular}

Dept. of Obstet. \& Gynec., University of Kiel, 1988 
Both fetuses with an umbilical cord arterial $\mathrm{pH}<7.0$ were from primiparous mothers who had been vaginally delivered following a protracted labour, i.e. induction of labour as a result of primary uterine dysfunction.

In two patients complications such as umbilical cord prolapse or premature detachment of the placenta (abruptio) proved to be responsible for a low umbilical arterial PH following Caesarean Section.

\section{Discussion}

According to the opinion of most investigators premature breech presentation infants should be delivered per Caesarean Section in order to decrease perinatal morbidity and mortality $[3,6,12$, 19]. Because the rate of prematurity is higher in the case of breech presentation than that of vertex presentations $(22.6 \%$ to $8.7 \%)$, several authors supported a prevention of premature births in order to decrease breech presentation morbidity and mortality $[17,21]$. In the mature infant in the breech presentation the recommendations vary from a generalised Section at term or at the onset of labour $[14,15,22]$ to a programmed delivery also in the case of a primapara [7].

The perinatal mortality of infants in the breech presentation is pointed out only by a few authors with regards to its dependence on the weight of the fetus and on the mode of delivery $[7,11,17$, 21]. The quoted value for perinatal mortality of mature vaginally delivered infants from breech presentation varies according to most recent studies between $0 \%[7,11]$ to $0.7 \%$ (5 of 750 fetuses) [21]. All mature breech presentation infants in our collective who died, also showed severe malformations incompatible with life. The fetal umbilical arterial PH appears to have a special value in the determination of "fetal outcome". Again most investigators did not point out selectively the um- bilical arterial PH of mature and immature infants in breech presentation with its dependence on the mode of delivery. GösCHEN [7] stated that he did not find any $\mathrm{PH}$ below 7.10 in 71 programmed deliveries of mature infants in breech presentation. We found a $\mathrm{PH}$ of below 7.0 in $2.5 \%$ (2 fetuses) post-vaginal delivery. Both cases were deliveries of primiparous patients with a protracted labour or primary uterine dysfunction given early assistance by Oxytocin infusion. We could not prove a statistically significant difference in the mean umbilical cord arterial $\mathrm{PH}$ between the vaginally delivered breech presentation and the vertex presentation groups. The single case analysis of the vaginally delivered infants from breech presentation with a low umbilical cord arterial $\mathrm{PH}$ shows that the indication leading to secondary section should be generously applied. In cases of prolonged labour a Section should be carried out.

It is because of these previously mentioned cases that we are reluctant to recommend programmed deliveries in primiparous patients. According to HÜTER [9] the maternal mortality per Caesarean Section is threefold, according to MoLDIN [20] it is twelve times greater than the maternal mortality per vaginal delivery. When making the decision as to the mode of delivery, one should take not only perinatal morbidity and mortality into consideration but also late morbidity. The presently existing results regarding this problem remain divergent $[4,5,8,13]$. Minimal neurological dysfunctions such as hyperkinesia and motoric disturbances appear to be more frequent post vaginal delivery from breech presentation than post Section. When selecting the mode of delivery the raised maternal mortality of Caesarean Section has to be weighed in consideration against the increased risk of perinatal and fetal morbidity post vaginal delivery. Because of the results presented in our study, we do not support a generalised practice of Caesarean Section in infants with breech presentation.

\begin{abstract}
304 breech presentation infants $\geqslant 2.500 \mathrm{~g}$ were delivered at the University Womens Clinic, Kiel, between 1984 and 1987. Only 2 of the vaginally delivered infants died; both had severe malformations sonographically diagnosed prior to delivery.

The umbilical cord arterial PH was found to be significantly $(p<0.001)$ higher in infants delivered per Cae-
\end{abstract}

sarean Section as compared to those vaginally delivered. The same ratio was found in a control group of vaginally delivered infants compared to sectioned infants in the vertex presentation. In $13.3 \%$ of cases post primary section and in $14.4 \%$ of cases post vaginal delivery from breech presentation we found an apgar of $\leqslant 7$ one minute post-partum. The transfer rate to a paediatric 
unit of vaginally delivered infants (7.2\%) appeared to be double that of the infants delivered per Caesarean Section (3.6\%). However, the indication for transferral is principally independent of the mode of delivery. Taking the 3-12fold increased maternal mortality rate post section as compared to vaginal delivery into consideration, a vaginal delivery of a breech presentation infant at term appears to be justifiable under certain presuppositions: exclusion of cranio-pelvic disproportion, and normal progression of labour.

The indication for secondary Caesarean Section should be generously applied in cases of a suspicious C.T.G. and a slow progression of labour.

Keywords: Breech presentation, delivery by Caesarean Section, perinatal morbidity, umbilical cord arterial blood $\mathrm{PH}$, vaginal delivery.

\section{Zusammenfassung}

Entbindung des reifen Beckenendlagen-Kindes. Eine Analyse von 304 Beckenendlagen-Entbindungen

304 Beckenendlagen-Kinder $\geqslant 2.500 \mathrm{~g}$ wurden von 1984 bis 1987 an der Universitäts-Frauenklinik Kiel entbunden. Der Anteil der vaginalen Entbindungen stieg von $11,5 \%$ im Jahre 1984 auf 38\% im Jahre 1987 an. Lediglich zwei vaginal entbundene Kinder mit präpartal sonographisch gesicherten schweren Mißbildungen verstarben. Bei den durch Sectio entbundenen Kindern war kein Todesfall aufgetreten. Die perinatale Morbidität wurden anhand des Apgar-Index, der Verlegungsfrequenz in die Kinderklinik und des arteriellen Nabelschnur-pH (NSpHart.) untersucht. Der arterielle Nabelschnur-pH der durch Sectio entbundenen lag signifikant $(p<0,001)$ über dem vaginal entbundenen BEL-Kindern (Tab. III). Das gleiche Verhältnis zeigte ein Kontrollkollektiv von vaginal und durch Sectio entbundener Kinder aus Schädellage (Tabelle IV).
In $13,3 \%$ nach primärer Sectio und in $14,4 \%$ nach vaginaler Entbindung aus Beckenendlage fand sich ein Apgar $\leqslant 7$ eine Minute post partum. Die Verlegungsfrequenz in die Kinderklinik waren nach vaginaler Entbindung doppelt so hoch $(7,2 \%)$ als nach primärer Sectio $(3,6 \%)$. Die Indikationen zur Verlegung sind jedoch im wesentlichen unabhängig vom Entbindungsmodus. In Anbetracht der gegenüber der Müttersterblichkeit 3-12fachen höheren Sectiomortalität erscheint unter bestimmten Voraussetzungen, Ausschluß eines Mißverhältnisses zwischen kindlichem Kopf und mütterlichem Becken, zügiger Geburtsfortschritt, die vaginale Entbindung des reifen Beckenendlagen-Kindes vertretbar. Die Indikationen zur sekundären Sectio ist bei suspektem CTG sowie protrahiertem Geburtsverlauf großzügig zu stellen.

Schlüsselwörter: Arterieller Nabelschnur-pH, Beckenendlage, Kaiserschnittentbindung, perinatale Morbidität, vaginale Entbindung.

\section{Résumé}

Accouchement des enfants à terme en présentation du siège. Analyse de 304 accouchements par le siège

304 enfants $\geqslant 2500 \mathrm{~g}$ sont nés en présentation du siège à la clinique universitaire des femmes de KIEL de 1984 à 1987. Le pourcentage de voies basses pendant cette période s'est élevé de $11,5 \%$ en 1984 à $38 \%$ en 1987 . Deux enfants seulement nés par voie basse sont décédés; tous deux avaient de graves malformations diagnostiquées à l'échographie avant l'accouchement. On a étudié la morbidité périnatale selon les paramètres suivants: scores d'Apgar, taux de transfert en unité pédiatrique et $\mathrm{pH}$ artériel ombilical.

Le $\mathrm{pH}$ artériel ombilical est significativement $(\mathrm{p}<0,001)$ plus élevé chez les enfants nés par césarienne en comparaison avec ceux qui sont nés par voie basse (tableau III). On a retrouvé le même ratic dans un groupe contrôle d'enfants nés par voie basse ou par césarienne en présentation céphalique (tableau IV). L’Apgar est $\leqslant 7$ à une minute dans $13,3 \%$ des césariennes et dans 14,4 des voies basses. Le taux de transfert en unité pédiatrique est le double pour les enfants nés par voie basse $(7,2 \%)$ de celui des enfants nés par césarienne $(3,6 \%)$. Toutefois, l'indication du transfert est le plus souvent indépendante du mode d'accouchement.

Si l'on prend en considération le taux de mortalité maternelle 3 à 12 fois plus élevée pour les césariennes que pour les voies basses, la naissance par voie basse d'un enfant à terme en présentation du siège apparaît comme légitime sous certaines conditions: absence de disproportion céphalopelvienne et progression normale du travail.

L'indication d'une césarienne secondaire doit être largement posée lorsque le CTG est pathologique et lorsque le travail progresse lentement.

Mots-clés: Accouchement par césarienne, accouchement par voie basse, morbidité périnatale, $\mathrm{pH}$ du sang artériel ombilical, présentation du siège. 


\section{References}

[1] Berg D, H Albrecht, JW Dudenhausen, E HoCHULI, G NeUhäuser, HT Versmold, M Brand, TKAB Eskes, F Kubli, A Staudach, H Wulf: Bericht der Standardkommission "Beckenendlage". Z. Geburtsh u Perinat 188 (1984) 100

[2] Döring GK, AJ DE Sousa Gerbat: Zum Wandel der Beckenendlagenentbindungen. Geburtsh u Frauenheilk 48 (1988) 150

[3] Duenhoelter JH, CE Wells, JS Reisch, R SantosRAMOS, JM JIMENEZ: A Paried Controlled Study of Vaginal and Abdominal Delivery of the Low Birth Weight Breech Fetus. Obstet Gynecol 54 (1979) 310

[4] Faber-Nijholt R, HJ Huisjes, BCC Touwen, VJ FIDLER: Neurological Follow-up of 281 Children Born in Breech Presentation: A Controlled Study. Brit Med J 286 (1983) 9

[5] Fianu S, I Joelsson: Minimal Brain Dysfunction in Children Born in Breech Presentation. Acta Obstet Gynecol Scand 58 (1979) 295

[6] Frenzel J, W Krause, I SANDER, W Michels: Zur Früh- und Spätmorbidität mindergewichtiger Neugeborener (LBWI) nach Beckenendlage in Abhängigkeit vom Entbindungsmodus. Z Geburtsh Perinat 188 (1984) 261

[7] GOESCHEN K: Die programmierte BeckenendlagenGeburt. Geburtsh u Frauenheilk 37 (1977) 311

[8] Hochuli E, O KäCH: Die Beckenendlage. Geburtsh u Frauenheilk 41 (1981) 23

[9] HÜTER J: Die aktuelle mütterliche Sectio-Morbidität und Mortalität in der BRD. Gynäkol 8 (1975) 19

[10] Jung H, F Kubli, H Schmidt-Matthiesen: Behandlung der Beckenendlage. Gynäkol Prax 1 (1977) 421

[11] Karl C, H Jung, M Peters: Perinatale Mortalität und Azidosemorbidität bei Entbindung aus Bekkenendlage und Schädellage. Z Geburtsh u Perinat 186 (1982) 196

[12] KraUSE W, W Michels, H Kunath: Überwachung und Entbindung des unreifen BeckenendlagenKindes. Zbl Gynäkol 100 (1978) 1062
[13] Krause W, KH Daute, G Thiele, EM FuhrmeisTER, J BURGMEIER, J DONCZIK, W Michels: Morbiditätsuntersuchungen bei Beckenendlagen-Kindern nach vaginaler und abdominaler Geburt, bezogen auf reife und untergewichtige Kinder. Z Geburtsh u Perinat 188 (1984) 80

[14] Kubli F, H Rüttgers, M Meyer-Menk: Die fetale Azidosegefährdung bei vaginaler Geburt aus Bekkenendlage. Z Geburtsh Perinat 179 (1975) 1

[15] KUBLI F: Geburtsleitung bei Beckenendlagen. Gynäkol 8 (1975) 48

[16] ManN LI, JM Gallant: Modern Management of the Breech Delivery. Amer J Obstet Gynecol 134 (1979) 611

[17] Manzl J, A Bichler, R Jesabek, J Klammer, O DAPUNT: Beckenendlage - ein Frühgeburtenproblem? Wien Klin Wschr 92 (1980) 483

[18] Mecke H, D Weisner, HH Riedel: Perinatale Morbidität bei Beckenendlage-Kindern in Abhängigkeit vom Geburtsmodus. Geburtsh u Frauenheilk 48 (1988) 41

[19] Mentzel M: Sectio bei Frühgeburt aus der Sicht des Neonatologen. Gynäkol 17 (1984) 243

[20] Moldin P, KH HöKEGARD, TF NIELSEN: Caesarean Seciton and Maternal Mortality in Sweden 19731979. Acta Obstet Gynecol Scand 63 (1984) 7

[21] Weidenbacher A, BJ Klose, F Langer: Die Bekkenendlage und ihre Behandlung. Geburtsh u Frauenheilk 36 (1976) 820

[22] WRIGHT RC: Reduction of Perinatal Mortality and Morbidity in Breech Delivery through Routine Use of Ceasarean Sectio. Obstet Gynec 14 (1959) 758

Received August 2, 1988. Accepted February 23, 1989.

Dr. med. Herbert Mecke

Universitäts-Frauenklinik Kiel

und Michaelis-Hebammenschule

Michaelisstr. 16

D-2300 Kiel 1, West-Germany 